\title{
Estrogen receptor $\beta$ is associated with expression of cancer associated genes and survival in ovarian cancer
}

\author{
Susanne Schüler-Toprak ${ }^{1 * \dagger}$, Florian Weber ${ }^{2 \dagger}$, Maciej Skrzypczak ${ }^{3}$, Olaf Ortmann ${ }^{1}$ and Oliver Treeck
}

\begin{abstract}
Background: In ovarian cancer, the role of estrogen receptors (ERs), particularly of ER $\beta$, being suggested as tumor suppressor in breast and prostate cancer, remains unclear. We examined the expression of nuclear and cytoplasmic ERB in ovarian cancer and correlated it with expression of ovarian cancer markers CA125, CEA and CA72-4, steroid hormone receptors ERa and PR, cancer-associated genes EGFR, p53, HER2 and proliferation marker Ki-67. Additionally we examined to what extent expression of ER $\beta$ and the other proteins affects survival of ovarian cancer patients.
\end{abstract}

Methods: We established a tissue microarray from 171 ovarian cancer patients and performed immunohistochemical analyses of the mentioned proteins.

Results: Nuclear ER $\beta$ was detected in $47.31 \%$ of the ovarian cancer tissues and cytoplasmic expression of this receptor was observed in $23.08 \%$. Nuclear expression of ER $\beta$ was significantly decreased in the G3 subgroup compared to better differentiated cancers $(p<0.01$ ) and correlated with ovarian cancer markers CEA (95\% Cl 0.1598-0.4465; $p<0.0001$ ) and CA72-4 (95\% Cl 0.05953-0.3616; $p<0.01$ ). Cytoplasmic ERß expression correlated with EGFR levels (95\% Cl 0. 1059-0.4049; $p<0.001)$. ERa expression was associated with expression of CA125 and PR. Overall survival of patients with tumors expressing cytoplasmic ER $\beta$ was significant longer compared to those with ERß-negative ovarian cancer (chi-square statistic of the log-rank, $p<0.05$ ). Progression-free survival was dependent on expression of PR (chi-square statistic of the log-rank, $p<0.05)$ and Ki-67 $(p=0.05)$.

Conclusions: Our data suggest an important, but distinct role of nuclear and cytoplasmic ER $\beta$ expression in ovarian cancer and encourage further studies on its role in this cancer entity.

Keywords: Estrogen receptor $\beta$, Ovarian cancer, Overall survival, Progression-free survival

\section{Background}

Ovarian cancer is the leading cause of death from a gynecological malignancy in the developed world [1]. Ovarian cancers are influenced by steroid hormones. Antiestrogenic treatment inhibits growth of ovarian cancer in vitro and in vivo [2-4]. Progesterone receptor (PR) and ER expression are reported to be associated with improved ovarian cancer survival, independent of clinical prognostic factors, but these associations have not been consistently repeated $[5,6]$. In the clinical setting antiestrogens are commonly used in patients with

\footnotetext{
* Correspondence: susanne.schueler@klinik.uni-regensburg.de

†'Susanne Schüler-Toprak and Florian Weber contributed equally to this work.

${ }^{1}$ Department of Obstetrics and Gynecology, University Medical Center

Regensburg, Landshuter Str. 65, 93053 Regensburg, Germany

Full list of author information is available at the end of the article
}

relapsed ovarian cancers after multiple lines of cytostatic therapies that have exhausted further treatment. Available data remains inconclusive, mostly due to heterogeneity of ovarian cancers and inadequate study settings as low number of included patients, missing subgroup analyses and absent evaluation of ER expression. However, use of tamoxifen and aromatase inhibitors have effects in a certain subgroup of patients $[7,8]$.

Previous studies clearly suggest a tumor suppressive role of ER $\beta$ in ovarian cancer as it has been shown for breast or prostate cancer [9-11]. Our group demonstrated that ER $\beta$ reduces proliferation and migration, but activates apoptosis of ovarian cancer cells [12] and that specific ER $\beta$-agonists significantly inhibit growth of different ovarian cancer cell lines [13]. Furthermore, our

(c) The Author(s). 2018 Open Access This article is distributed under the terms of the Creative Commons Attribution 4.0 International License (http://creativecommons.org/licenses/by/4.0/), which permits unrestricted use, distribution, and 
results from a phenotype-genotype association study suggested that the single nucleotide polymorphism rs3020449 in the promoter region of ESR2 gene might affect progression of ovarian cancer [14].

$E R \beta$ is the predominant ER in normal ovarian tissue. In ovarian cancer the expression of ER $\beta$ is significantly lower and the $E R \alpha / E R \beta$ ratio is significantly higher than in normal ovarian tissue [15-17]. High expression of ER $\beta$ in ovarian cancers is associated with a better progression-free and overall survival $[15,17]$.

Ovarian cancer marker cancer antigen 125 (CA125) is overexpressed in the majority of ovarian cancers and it has been shown to be involved in the metastatic process [18]. CA125 regulates cell adhesion by interacting with mesothelin, galectin-1, E-cadherin and $\beta$-catenin $[18,19]$. Moreover, CA125 can promote proliferation and migration [20]. Also for the broad spectrum tumor marker carcinoembryonic antigen (CEA) a regulative role of cell adhesion and thus an influence on metastasis of cancer cells has been suggested [21]. Another antigen selectively expressed in ovarian cancer is CA72-4. As it is highly detectable in all ovarian cancer subtypes it is another effective tumor marker in ovarian cancer [22]. However, its function in carcinogenesis of ovarian cancer is still unknown.

Recently, it has been reported that a shuffle of ER $\beta$ between nucleus and cytoplasm plays important roles in regulation of gene transcription, RNA maturation and post-transcriptional control [23]. To further approach the significance of subcellular ER $\beta$ localization in ovarian cancer, we examined co-expression of nuclear and cytoplasmic ER $\beta$ with various cancer-associated genes and steroid hormone receptors and tested to what extent receptor localization would affect survival of ovarian cancer patients.

\section{Methods}

\section{Tissue samples}

We included ovarian cancer samples collected in the Department of Gynecology and Obstetrics of the University of Regensburg. Caucasian women with sporadic ovarian cancer and available information on grading, stage, and histological subtype from 1995 to 2013 were included. Data from the Tumor Centre Regensburg (Bavaria, Germany), a high-quality population-based regional cancer registry of the districts of Upper Palatinate and Lower Bavaria, were analysed. Mortality data were obtained from regional registration offices. The institutional review board "Ethikkommission der Universität Regensburg" approved the retrospective study.

\section{Tissue microarray and immunohistochemistry}

The tissue microarray (TMA) was created using standard procedures that have been previously described [24].
From all patients included in this study, an experienced pathologist evaluated H\&E sections of tumor tissue and representative areas were marked. From each tumor, one single core was included in the final TMA. From these areas, core biopsies on the corresponding paraffin blocks were removed and transferred into the grid of a recipient block according to a predesigned array of about 60 specimens in each of five TMA paraffin blocks.

For immunohistochemistry, $4 \mu \mathrm{m}$ sections of the TMA blocks were incubated with the indicated antibodies (Additional file 1) according to routine protocols in the given dilutions, followed by incubation with an HRPconjugated secondary antibody and another incubation with 3,3'-diaminobenzidine (DAB) as substrate, which resulted in a brown-colored precipitate at the antigen site. An experienced clinical pathologist evaluated immunohistochemical staining according to localization and specificity. For steroid hormone receptors $E R \alpha$, nuclear ER $\beta$ and PR, the immunoreactivity score (IRS) according to Remmele et al. was used [25], wherein the percentage of stained nuclei in a 5 -tiered scale $(0 \%=0$, $1-9 \%=1,10-50 \%=2,51-80 \%=3$ and $81-100 \%=4)$ is multiplied with the staining intensity on a 4-tiered scale (no staining $=0$, weak staining $=1$, moderate staining $=2$, strong staining $=3$ ), resulting in an IRS ranging between 0 (completely negative) and 12 (strongly positive).

Expression of proliferation marker Ki-67 using antibody clone MIB-1 was assessed in the percentage of tumor cells with positive nuclear staining. Her2/neu expression was scored according to the DAKO score routinely used for breast cancer cases. EGFR was scored according to Spaulding et al. [26] on a 4-tiered scale from 0 to 3. EGFR expression was considered present when membranous staining was stronger than unspecific or cytoplasmic background staining, irrespective of complete or incomplete circumferential staining. Score 1 was defined as incomplete and weak membranous staining in $>1 \%$ of tumor cells, score 2 as moderate staining and score 3 as strong membranous staining in $>1 \%$ of tumor cells.

For p53 and polyclonal CEA, the "quickscore" was used, where results are scored by multiplying the percentage of positive cells $(\mathrm{P})$ by the intensity (I) according to the formula: $\mathrm{Q}=\mathrm{P}$ x I; maximum $=300$ [27]. CA-125 and cytoplasmic ER $\beta$ were described as positive or negative, irrespective of staining intensity. CA72-4 expression was assessed on a 4-tiered scale, wherein no expression equaled score 0 , weak cytoplasmic and/or membranous staining in $>1 \%$ of tumor cells equaled score 1 , moderate staining score 2 and strong staining corresponded to score 3 (if $>50 \%$ of tumor cells, otherwise score 2 ).

\section{Statistical analysis}

Statistical analysis was performed using GraphPad Prism $5^{\circ}$ (GraphPad Software, Inc., La Jolla, CA, USA). The 
non-parametric Kruskal-Wallis rank-sum test was used for testing differences in receptor expression among three or more groups. For pairwise comparison the nonparametric Mann-Whitney-U rank-sum test was used. Correlation analysis was performed using the Spearman correlation coefficient. The chi-square statistic of the log-rank was used to investigate differences between survival curves. $P$-values below 0.05 were considered statistically significant.

\section{Results}

\section{Characteristics of included patients and their tumors}

In this study, we used tissue from 171 Caucasian women with sporadic ovarian cancer and a median age at diagnosis of 63.5 years (range 29-91). The histopathological characteristics of the patients are shown in Table 1. $63.7 \%$ of the tumors were diagnosed in FIGO (International Federation of Gynaecologists and Obstetricians) stages III and IV (38.6 and 25.15, respectively). Most of the tumors were serous $(78.36 \%)$ and $64.3 \%$ of the tumors were grade 3 . Median follow-up time was 1180 days. 80 relapses and 62 deaths were documented. Median relapse free survival was 1044 days and median overall survival was 1673 days.

\section{Expression of steroid hormone receptors in ovarian cancer tissue}

Nuclear ER $\beta$ was expressed in $47.31 \%$, and cytoplasmic expression of this receptor was detected in $23.08 \%$ of ovarian cancer specimens (Fig. 1, Table 2). Nuclear ER $\beta$ expression was found to be lower in the subgroup of G3

Table 1 Staging and histopathological characteristics of ovarian cancer cases

\begin{tabular}{lll}
\hline Characteristics & Number of patients & $(\%)$ \\
\hline Ovarian cancer patients & 171 & \\
FIGO stage & 23 & $(13.45)$ \\
FIGO I & 9 & $(5.26)$ \\
FIGO II & 66 & $(38.60)$ \\
FIGO III & 43 & $(25.15)$ \\
FIGO IV & 30 & $(17.54)$ \\
unknown & & \\
Histological subtype & 134 & $(78.36)$ \\
serous & 6 & $(3.51)$ \\
mucinous & 10 & $(5.85)$ \\
endometrioid & 5 & $(2.92)$ \\
clear cell & 16 & $(9.36)$ \\
undifferentiated & & \\
Histological grade & 47 & $(27.49)$ \\
G2 & 110 & \\
G3 & 14 & $(8.19)$ \\
unknown & &
\end{tabular}

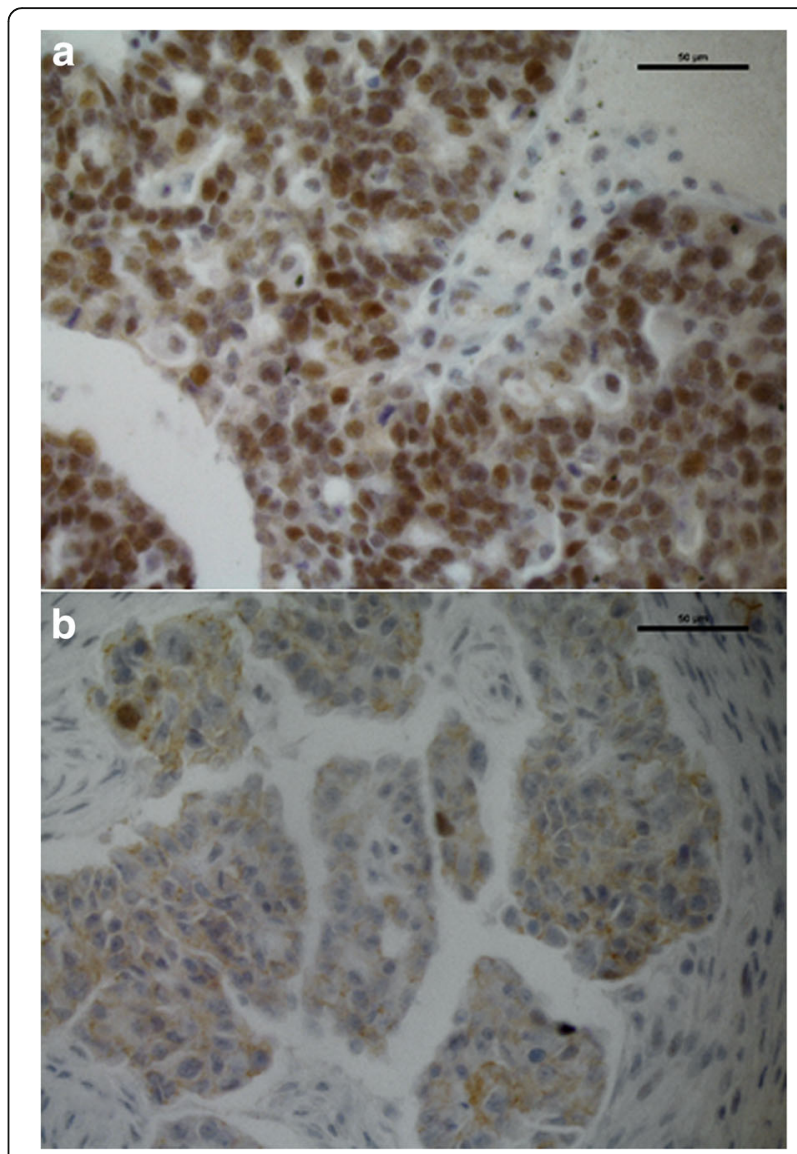

Fig. 1 Immunohistochemical staining patterns of ERß: a Moderate to strong nuclear expression of ER $\beta$. $\mathbf{b}$ Weak cytoplasmic expression of ER $\beta$

tumors than in better differentiated cancer specimens $(p<0.05)$ (Table 3, Fig. 2). ER $\alpha$ was expressed in $70.35 \%$ of all ovarian cancer samples, whereas PR was detected in $33.33 \%$ of the samples. PR expression was higher in FIGO I + II tumors than in the FIGO III + IV subgroup $(p<0.05)$ (Table 3). A significantly higher expression of PR was also found in tumors without invasion of lymphatic vessels compared to those with invasion. As serous ovarian cancer was the most common histological subtype, we further analysed this group and found similar rates of positive receptor expression. The subgroup of G3-tumors and those of stage III and IV also did not show significant differences. Further subgroup-analyses as well as analyses of other variables as residual disease after initial surgery, age at diagnosis or invasion of venous vessels did not reveal significant results because of the low number of included cases.

\section{Nuclear ER $\beta$ expression levels positively correlate with expression of CEA and CA72-4}

Subsequently, we investigated correlations between the expression levels of ER $\beta$ and ER $\alpha$, PR, CA125, CEA, CA72-4, EGFR, HER2, Ki-67 and p53. 
Table 2 Steroid hormone receptor expression in ovarian cancer: rate of expression of the indicated receptors

\begin{tabular}{llllll}
\hline & & ERa & ERß (nuclear) & ERß (cytoplasmic) & PR \\
\hline All & All & $121 / 172(70.35)$ & $79 / 167(45.04)$ & $39 / 169(23.08)$ & $55 / 165(33.33)$ \\
& G2 & $33 / 47(70.21)$ & $29 / 46(63.04)$ & $12 / 46(26.09)$ & $15 / 47(31.91)$ \\
& G3 & $78 / 111(70.27)$ & $45 / 109(41.28)$ & $19 / 109(17.43)$ & $36 / 106(33.96)$ \\
& FIGO I+ II & $21 / 32(70.54)$ & $12 / 30(40.00)$ & $7 / 31(22.58)$ & $16 / 31(51.61)$ \\
Serous & FIGO III + IV & $79 / 112(65.63)$ & $45 / 100(45.00)$ & $7 / 31(22.58)$ & $31 / 108(28.70)$ \\
& Serous & $99 / 133(74.44)$ & $59 / 131(49.62)$ & $27 / 131(20.61)$ & $46 / 128(35.94)$ \\
& G2 & $23 / 31(74.19)$ & $18 / 31(58.06)$ & $9 / 31(29.03)$ & $11 / 31(35.48)$ \\
& G3 & $71 / 97(73.20)$ & $38 / 95(40.00)$ & $17 / 95(17.89)$ & $33 / 92(35.87)$ \\
& FIGO I+ II & $15 / 20(75.00)$ & $5 / 19(26.32)$ & $6 / 20(30.00)$ & $12 / 19(63.16)$ \\
& FIGO III + IV & $70 / 96(72.92)$ & $45 / 95(47.37)$ & $19 / 92(20.65)$ & $28 / 92(30.43)$ \\
\hline
\end{tabular}

Shown are the numbers of positive samples in relation to the total numbers of ovarian cancer cases of the subgroups analysed and the corresponding percentage (in brackets)

We found a highly significant positive correlation between nuclear ER $\beta$ and ovarian cancer marker CEA $(p<0.0001 ; 95 \%$ confidence interval (CI) $0.1598-$ 0.4465) (Table 4). This significant correlation was also found in the serous subtype $(p<0.0001 ; 95 \% \mathrm{CI}$ $0.1770-0.4930)$. Moreover, we observed a highly significant correlation between nuclear ER $\beta$ and CA72-4 $(p<0.01 ; 95 \%$ CI $0.05953-0.3616)$ in all ovarian cancer specimens as well as in the serous subtype $(p<0.01$; 95\% CI 0.08939 to 0.4225 ).

\section{Cytoplasmic ER $\beta$ expression levels positively correlate with EGFR expression}

Additionally, we observed a significant correlation between cytoplasmic ER $\beta$ expression levels with expression of EGFR $(p<0.001 ; 95 \%$ CI 0.1059-0.4049). In serous ovarian cancers this effect reappeared $(p<0.01 ; 95 \%$ CI $0.06-0.4016)$ and we observed a significant correlation with PR expression $(p<0.05$; 95\% CI 0.02307-0.3688) (Table 5).

\section{ERa expression levels correlate with expression of CA125} and PR

Examining the correlation of ER $\alpha$ with different markers, we found a significant correlation between this receptor and CA125 ( $p<0.001 ; 95 \%$ CI 0.1188-0.4068), which was also observed in the serous subtype $(p<0.05 ; 95 \% \mathrm{CI}$ 0.03457-0.3702). The correlation between ER $\alpha$ and CA125 was also significant in the subgroups of G2 and G3 ovarian cancers $(p<0.01 ; 95 \%$ CI $0.1431-0.6367$ and $p<0.01 ; 95 \%$ CI 0.0567-0.4210, respectively) (Additional file 2).

The expression of ER $\alpha$ significantly correlated with expression of PR ( $p<0.0001 ; 95 \%$ CI $0.2143-0.4914)$, which was also observed in the subgroup of serous ovarian cancers $(p<0.0009 ; 95 \%$ CI $0.1188-0.4477)$,

Overall survival of patients expressing cytoplasmic ER $\beta$ is significant longer compared to those of patients with ER $\beta$-negative tumors

Survival analyses revealed a significant longer overall survival of patients with tumors expressing cytoplasmic

Table 3 Steroid hormone receptor expression in ovarian cancer: mean receptor expression levels in all ovarian cancer specimens

\begin{tabular}{|c|c|c|c|c|c|c|c|c|}
\hline & \multicolumn{2}{|l|}{$\mathrm{ERa}$} & \multicolumn{2}{|c|}{ ERß (nuclear) } & \multicolumn{2}{|c|}{ ERß (cytoplasmic) } & \multicolumn{2}{|l|}{$P R$} \\
\hline & Mean & $\overline{p \text {-value }}$ & Mean & $\overline{p \text {-value }}$ & Mean & $p$-value & Mean & $\overline{p \text {-value }}$ \\
\hline G2 & 4.30 & 0.9464 & 1.72 & 0.0466 & 0.26 & 0.4424 & 2.19 & 0.9202 \\
\hline G3 & 4.06 & & 1.07 & & 0.17 & & 1.19 & \\
\hline $\mathrm{FIGO} I+\|$ & 3.97 & 0.9172 & 1.27 & 0.6752 & 0.23 & 0.9548 & 3.48 & 0.0202 \\
\hline FIGO III + IV & 4.15 & & 1.28 & & 0.21 & & 1.06 & \\
\hline G2 & 4.26 & 0.9835 & 1.58 & 0.2049 & 0.29 & 0.4139 & 1.90 & 0.8961 \\
\hline G3 & 4.06 & & 1.12 & & 0.18 & & 1.18 & \\
\hline $\mathrm{FIGO} I+\|$ & 3.80 & 0.9338 & 0.79 & 0.2563 & 0.30 & 0.6205 & 3.37 & 0.0190 \\
\hline FIGO III + IV & 4.10 & & 1.31 & & 0.21 & & 1.05 & \\
\hline
\end{tabular}

A non-parametric Kruskal-Wallis rank-sum test was used for testing differences in receptor expression of estrogen receptor (ER) $a$, nuclear ER $\beta$, cytoplasmic ER $\beta$ and progesterone receptor $(P R)$ among the groups. $p$-values $<0.05$ were considered statistically significant (indicated by using bold font) 


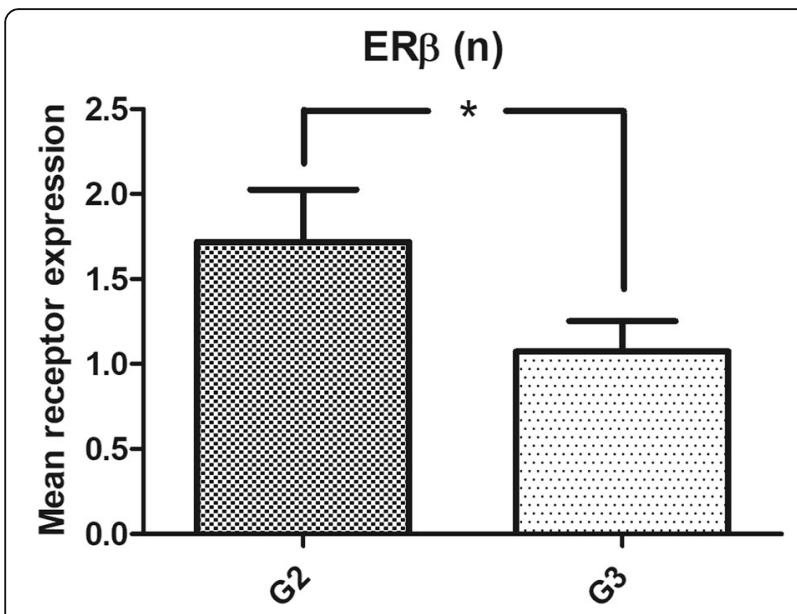

Fig. 2 Expression of nuclear ERß in G2 and G3 graded ovarian cancer. Shown are the mean values of the immunoreactivity scores $(p<0.05) \cdot \mathrm{n}(\mathrm{G} 2)=64, \mathrm{n}(\mathrm{G} 3)=109$

ER $\beta$ compared to those having ER $\beta$-negative tumors (chi-square statistic of the log-rank, $p<0.05$ ). Patients with ovarian cancers not expressing cytoplasmic ER $\beta$ had a median survival of 1628 days, whereas in the cohort with cytoplasmic ER $\beta$ expressing tumors, survival was still more than $50 \%$ at the longest time point (hazard ratio (HR) 1.842; 95\% CI 1.040-3.264) (Fig. 3).

\section{Longer progression-free survival of patients with ovarian} cancers expressing PR and with low Ki-67 expression

Patients with tumors expressing PR (IRS $\geq 1)$ had a significant longer progression-free survival compared to those with tumors not expressing PR (IRS 0) (chi-square statistic of the log-rank, $p<0.05$ ) (Fig. 4a). This significant difference was also observed in the subgroup of serous ovarian cancers (data not shown). Progression-free survival significantly differed in those patients with tumors expressing Ki-67 by more than $14 \%$ (chi-square statistic of the log-rank, $p<0.05$ ) (Fig. 4b). This effect also was visible in serous tumors (data not shown).

\section{Discussion}

Several studies showed a wide range of expression levels of steroid hormone receptors in ovarian cancer [28-30]. In our study including 171 ovarian cancer cases, 70.35\% of all cases were ER $\alpha$ positive. This is in line with the data of Lee et al. who found this receptor to be expressed in $77.3 \%$ of all cases [30]. In other studies, ER $\alpha$ was only expressed in $31.4-36 \%$ of ovarian cancer specimens $[28,29]$. These differences might be due to different applied ER $\alpha$ antibodies detecting a specific set of splice variants. Investigating ER $\beta$ expression reveals even more difficulties as specific antibodies have not been available for a long time. Moreover, it is important to distinguish between nuclear and cytoplasmic ER $\beta$ expression as their role in carcinogenesis differs [31, 32]. In our study, nuclear ER $\beta$ was expressed in $49.62 \%$ and cytoplasmic ER $\beta$ in only $20.61 \%$ of all cases. Other studies showed rates of positive ER $\beta$ expression between 48 and $60 \%$ [28, 33]. In the study of De Stefano et al. including 58 serous ovarian cancers nuclear ER $\beta$ was expressed in $89.66 \%$ and cytoplasmic ER $\beta$ was expressed in $77.59 \%$ [17].

As expression of ER $\beta$ declines during tumorigenesis of breast, colon and prostate cancer, this receptor has been proposed to act as a tumor suppressor [9-11, 34]. ER $\beta$ expression is highest in normal ovarian tissue whereas it decreases during dedifferentiation processes [16]. This is in line with our data showing a significantly lower expression of nuclear ER $\beta$ in G3 ovarian cancers than in better differentiated tumors. In vitro, we showed reduced proliferation and migration of ovarian cancer cells after overexpression of ER $\beta$ as well as increased rates of apoptosis [12]. Moreover, we found a significant growth-inhibition of ovarian cancer cells by treatment with specific ER $\beta$-agonists [13]. Thus, these data support the tumor suppressive role of ER $\beta$ in ovarian cancer.

In our study PR expression was significantly higher in early stage ovarian cancers than in cancers with FIGO stages III and IV $(p=0.0027)$. Moreover, we showed a significantly higher expression of PR in tumors without

Table 4 Correlation of nuclear ERß expression in ovarian cancer with expression of ovarian cancer markers, cancer-associated genes and steroid hormone receptors

\begin{tabular}{|c|c|c|c|c|c|c|c|c|c|c|}
\hline & & CA125 & CEA & CA72-4 & EGFR & HER2 & Ki-67 & P53 & $\mathrm{ERa}$ & $P R$ \\
\hline \multirow[t]{3}{*}{ All } & Spearman $r$ & -0.041 & 0.31 & 0.216 & 0.054 & 0.045 & -0.084 & 0.101 & 0.086 & 0.006 \\
\hline & $95 \% \mathrm{Cl}$ & $\begin{array}{l}-0.198 \\
-0.117\end{array}$ & $\begin{array}{l}0.16 \\
-0.447\end{array}$ & $\begin{array}{l}0.06 \\
-0.362\end{array}$ & $\begin{array}{l}-0.107 \\
-0.213\end{array}$ & $\begin{array}{l}-0.114 \\
-0.201\end{array}$ & $\begin{array}{l}-0.246 \\
-0.083\end{array}$ & $\begin{array}{l}-0.058 \\
-0.255\end{array}$ & $\begin{array}{l}-0.073 \\
-0.240\end{array}$ & $\begin{array}{l}-0.154 \\
-0.166\end{array}$ \\
\hline & $P$ value & n.s. & $<0.0001$ & 0.0057 & n.s. & n.s. & n.s. & n.s. & n.s. & n.s. \\
\hline \multirow[t]{3}{*}{ Serous } & Spearman $r$ & 0.051 & 0.345 & 0.264 & 0.089 & 0.098 & -0.061 & 0.067 & 0.095 & 0.011 \\
\hline & $95 \% \mathrm{Cl}$ & $-0.129-0.227$ & $\begin{array}{l}0.177 \\
-0.493\end{array}$ & $\begin{array}{l}0.089 \\
-0.423\end{array}$ & $-0.0940-0.266$ & $-0.083-0.274$ & $-0.245-0.128$ & $-0.113-0.242$ & $-0.084-0.269$ & $-0.170-0.193$ \\
\hline & $P$ value & n.s. & $<0.0001$ & 0.0026 & n.s. & n.s. & n.s. & n.s. & n.s. & n.s. \\
\hline
\end{tabular}

Correlation of nuclear ER $\beta$ expression with expression of ovarian cancer markers CA125, CEA, CA72-4, and with EGFR, HER2, Ki-67, P53, ERa and PR were calculated for all ovarian cancers ("all") and serous ovarian cancers ("serous") using the Spearman correlation coefficient. $P$-values below 0.05 were considered statistically significant (significant results were indicated by using bold font)

Cl confidence interval 
Table 5 Correlation of cytoplasmic ER $\beta$ with expression of cancer-associated genes and steroid hormone receptors

\begin{tabular}{|c|c|c|c|c|c|c|c|c|c|c|c|}
\hline & & CA125 & CEA & CA72-4 & EGFR & HER2 & Ki-67 & P53 & ERa & $E R \beta(n)$ & $P R$ \\
\hline \multirow[t]{3}{*}{ All } & Spearman $r$ & 0.073 & 0.036 & 0.026 & 0.262 & 0.089 & -0.012 & 0.037 & -0.049 & -0.085 & 0.131 \\
\hline & $95 \% \mathrm{Cl}$ & $\begin{array}{l}-0.086 \\
-0.227\end{array}$ & $\begin{array}{l}-0.122 \\
-0.193\end{array}$ & $\begin{array}{l}-0.132 \\
-0.183\end{array}$ & $\begin{array}{l}0.106 \\
-0.405\end{array}$ & $\begin{array}{l}-0.069 \\
-0.243\end{array}$ & $\begin{array}{l}-0.175 \\
-0.152\end{array}$ & $\begin{array}{l}-0.121 \\
-0.194\end{array}$ & $\begin{array}{l}-0.205 \\
-0.109\end{array}$ & $\begin{array}{l}-0.238 \\
-0.073\end{array}$ & $\begin{array}{l}-0.029 \\
-0.284\end{array}$ \\
\hline & $p$ value & n.s. & n.s. & n.s. & 0.0009 & n.s. & n.s. & n.s. & n.s. & n.s. & n.s. \\
\hline \multirow[t]{3}{*}{ Serous } & Spearman $r$ & -0.007 & 0.041 & -0.026 & 0.238 & 0.020 & 0.174 & 0.083 & -0.109 & -0.078 & 0.202 \\
\hline & $95 \% \mathrm{Cl}$ & $\begin{array}{l}-0.183 \\
-0.17\end{array}$ & $\begin{array}{l}-0.138 \\
-0.216\end{array}$ & $\begin{array}{l}-0.202 \\
-0.152\end{array}$ & $\begin{array}{l}0.06 \\
-0.402\end{array}$ & $\begin{array}{l}-0.158 \\
-0.197\end{array}$ & $\begin{array}{l}-0.010 \\
-0.346\end{array}$ & $\begin{array}{l}-0.095 \\
-0.257\end{array}$ & $\begin{array}{l}-0.281 \\
-0.07\end{array}$ & $\begin{array}{l}-0.252 \\
-0.099\end{array}$ & $0.023-0.3699$ \\
\hline & $p$ value & n.s. & n.s. & n.s. & 0.0075 & n.s. & n.s. & n.s. & n.s. & n.s. & 0.0231 \\
\hline
\end{tabular}

Correlations of cytoplasmic ER $\beta$ expression with expression of ovarian cancer markers CA125, CEA, CA72-4 and with EGFR, HER2, Ki-67, P53, ERa, nuclear ER 3 (n) and PR were calculated for all ovarian cancers ("all") and serous ovarian cancers ("serous") using the Spearman correlation coefficient. $P$-values below 0.05 were considered statistically significant (significant results were indicated by using bold font)

$\mathrm{Cl}$ confidence interval

invasion of lymphatic vessels compared to cancers that did not invade lymphatic vessels. In line with data published earlier, progression-free survival of patients with PR-expressing tumors was significantly longer compared to those with tumors not expressing PR [5, 28, 35]. This could be explained by an induction of apoptosis by PR activation in ovarian cancer [5]. Multiple in vitro studies have shown that increased PR expression could promote the progesterone-induced inhibition of DNA synthesis, cell division and proliferation in ovarian cancer cells $[35,36]$. Moreover, PR is transactivated by ER $\alpha$ and PR expression may be a biomarker of improved prognosis because it indicates a functionally intact ER pathway and less aggressive tumor behavior [5].

With regard to overall survival and progression-free survival, data from literature remain inconclusive. In our study, patients with tumors expressing cytoplasmic ER $\beta$ had a significant benefit in overall survival compared to those with tumors not expressing this form of ER $\beta$. A recent study revealed that ER $\beta$-positive nuclear staining was associated with decreased progression-free survival (hazard ratio (HR) 1.69; 95\% CI $0.91-3.15 ; p=0.096$ ) and decreased overall survival (HR 1.91; 95\% CI 0.94$3.89 ; p=0.075$ ) [37]. In the study by De Stefano et al. expression of cytoplasmic ER $\beta$ predicted poor clinical outcome in serous ovarian cancer. However, the study was smaller with 58 included ovarian cancer cases and only serous cases were included [17].

CA125 is overexpressed in the majority of serous ovarian cancers, the most common histological subtype [18]. We found a high correlation between the expression of ER $\alpha$ and the expression of CA125, which is in line with the findings of Sylvia et al. [38]. CA125 interacts with cell-adhesion regulators mesothelin, galectin- 1 and $\mathrm{E}$-cadherin and $\beta$-catenin $[18,19]$ and is involved in promotion of proliferation and migration [20]. Park et al. found an ER $\alpha$-dependent, estrogen-induced suppression of expression and promoter activity of E-cadherin in ovarian cancer cells, whereas epithelial-mesenchymal transition-associated transcription factors, Snail and Slug, were significantly up-regulated [39].

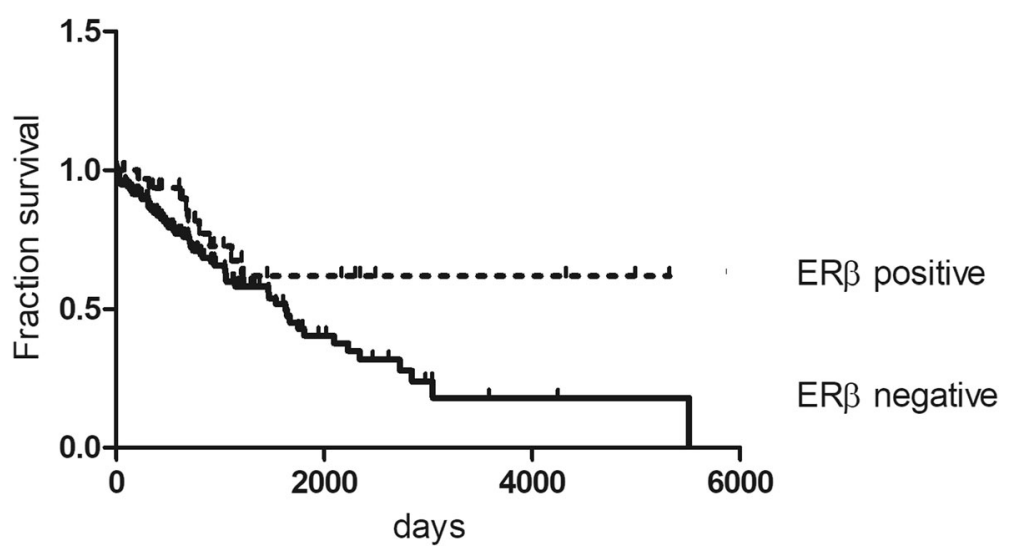

Fig. 3 Kaplan Meier survival analysis in ovarian cancer in relation to cytoplasmic ERß expression. Overall survival of patients with absent expression of cytoplasmic ER $\beta$ was compared to survival of patients with cytoplasmic ER $\beta$ expression ( $p=0.0362)$. The chi-square statistic of the log-rank was used to investigate differences between survival curves. P-values below 0.05 were considered statistically significant 

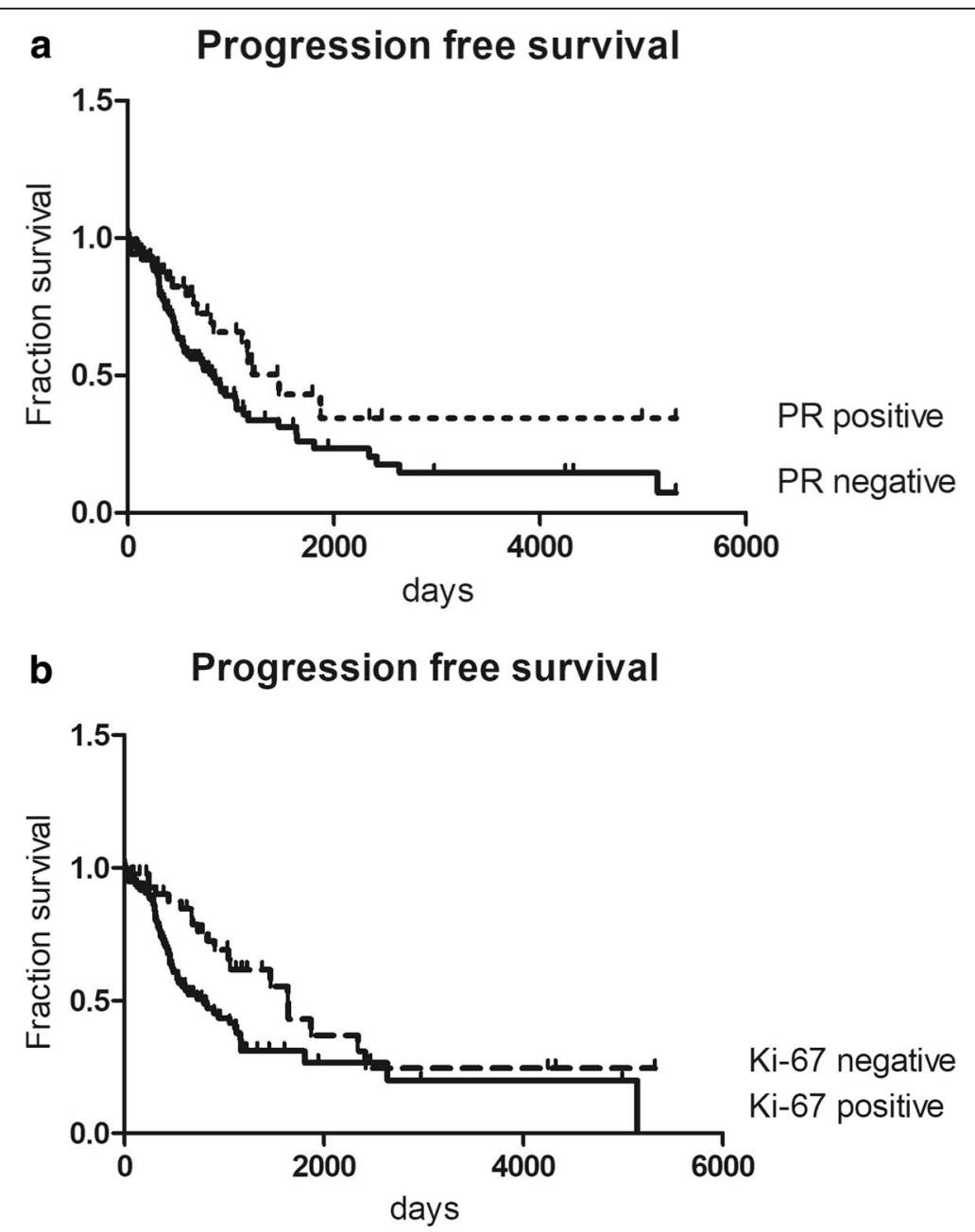

Fig. 4 Kaplan Meier survival analysis of progression-free survival (PFS). a PFS in all ovarian cancer cases in relation to PR expression. PFS of patients without expression of PR was compared to survival of patients with PR expression $(p=0.0261)$. The chi-square statistic of the log-rank was used to investigate differences between survival curves. P-values below 0.05 were considered statistically significant. PFS of those patients whose tumors express PR (IRS $\geq 1$ ) compared to those with PR negative tumors (IRS 0); $\mathbf{b}$ PFS of ovarian cancer patients whose tumors expressing Ki-67 compared to those with low or absent Ki-67 expression $(p=0.0134)$

Thus, this possible interaction between CA125 and ER $\alpha$ in regulation of cell adhesion should be elucidated in future studies. Also CEA has a regulative function in cell adhesion and thus an influence on metastasis of cancer cells has been suggested [21]. Another antigen selectively expressed in ovarian cancer is CA72-4. As it is highly detectable in all ovarian cancer subtypes it is another effective tumor marker in ovarian cancer [22]. However, its function in carcinogenesis of ovarian cancer is still unknown. We were able to show a high correlation between the expression of nuclear ER $\beta$ and CEA as well as CA72-4. Moreover, we observed a significant correlation between expression of ER $\alpha$ and PR (Additional file 2), which is in line with studies published earlier $[28,40]$.

As discussed above, the role of ER $\beta$ as a tumor suppressor in ovarian cancers is still controversial. Our data and those published by others clearly suggest a contradictory role of nuclear and cytoplasmic ER $\beta$. Our results demonstrating an improvement of overall survival for patients with ovarian cancers expressing cytoplasmic ER $\beta$ corroborate a tumor suppressive role of ER $\beta$. In contrast, nuclear expression of this receptor previously has been reported to shorten progression-free survival [37]. This is in accordance with our finding that expression of nuclear ER $\beta$ is associated with tumor markers CEA and CA72-4. Different binding partners depending on the subcellular location of ER $\beta$ might explain these effects [23]. Our data suggest that future studies should further assess the different roles of nuclear and cytoplasmic ER $\beta$ in ovarian cancer as previous controversial results might be due to a distinct function of $E R \beta$ depending on its location. 


\section{Conclusions}

To our knowledge, we are the first to show a correlation between nuclear ER $\beta$ and CEA as well as CA72-4 expression in ovarian cancer. Moreover, our data support the role of ER $\beta$ as a tumor suppressor in ovarian cancer, as our survival analyses show a significant benefit in overall survival of patients with tumors expressing cytoplasmic ER $\beta$. Further studies will be necessary to examine the relevance of our data in the clinical setting.

\section{Additional files}

Additional file 1: Antibodies used in this study. (DOCX $12 \mathrm{~kb}$ )

Additional file 2: Correlation of ERa expression in ovarian cancer with expression of cancer-associated genes and PR. (DOCX $19 \mathrm{~kb}$ )

\section{Abbreviations}

CA125: Cancer antigen 125; CEA: Carcinoembryonic antigen; DAB: 3,3'diaminobenzidine; ER: Estrogen receptor; IRS: Immunoreactivity score; PR: Progesterone receptor; TMA: Tissue microarray; FIGO: International Federation of Gynaecologists and Obstetricians

\section{Availability of data and materials}

The datasets used and/or analysed during the current study are available from the corresponding author on reasonable request.

\section{Authors' contributions}

SST made substantial contributions to conception and design, acquisition of data analysis and interpretation of data. FW made substantial contributions to acquisition of data. MS made substantial contributions to acquisition of data. $\mathrm{OO}$ has been involved in revising the manuscript critically for important intellectual content. OT made substantial contributions to conception and design, acquisition of data analysis and interpretation of data. All authors read and approved the final manuscript.

\section{Ethics approval and consent to participate}

The institutional review board "Ethikkommission der Universität Regensburg" approved the retrospective study.

\section{Consent for publication}

Not applicable

\section{Competing interests}

The authors declare that they have no competing interests.

\section{Publisher's Note}

Springer Nature remains neutral with regard to jurisdictional claims in published maps and institutional affiliations.

\section{Author details}

${ }^{1}$ Department of Obstetrics and Gynecology, University Medical Center Regensburg, Landshuter Str. 65, 93053 Regensburg, Germany. 'Department of Pathology, University Medical Center Regensburg, Franz-Josef Strauß Allee 11, 93053 Regensburg, Germany. ${ }^{3}$ Second Department of Gynecology, Medical University of Lublin, Jaczewskiego 8, 20-090 Lublin, PL, Poland.

Received: 5 July 2018 Accepted: 3 October 2018

Published online: 16 October 2018

\section{References}

1. Siegel RL, Miller KD, Jemal A. Cancer statistics, 2015. CA Cancer J Clin. 2015; 65(1):5-29.

2. O'Donnell AJ, Macleod KG, Burns DJ, Smyth JF, Langdon SP. Estrogen receptor-alpha mediates gene expression changes and growth response in ovarian cancer cells exposed to estrogen. Endocr Relat Cancer. 2005;12(4): 851-66.
3. Langdon SP, Langdon SP, Hawkes MM, Hawkes MM, Lawrie SS, Lawrie SS, Hawkins RA, Hawkins RA, Tesdale AL, Tesdale AL et al. Oestrogen receptor expression and the effects of oestrogen and tamoxifen on the growth of human ovarian carcinoma cell lines. Br J Cancer. 1990;62(2):213-16.

4. Langdon SP, Crew AJ, Ritchie AA, Muir M, Wakeling A, Smyth JF, Miller WR. Growth inhibition of oestrogen receptor-positive human ovarian carcinoma by anti-oestrogens in vitro and in a xenograft model. Eur J Cancer. 1994; 30A(5):682-6.

5. Sieh W, Kobel M, Longacre TA, Bowtell DD, de Fazio A, Goodman MT, Hogdall E, Deen S, Wentzensen N, Moysich KB, et al. Hormone-receptor expression and ovarian cancer survival: an ovarian tumor tissue analysis consortium study. Lancet Oncol. 2013;14(9):853-62.

6. Sinn BV, Darb-Esfahani S, Wirtz RM, Budczies J, Sehouli J, Chekerov R, Dietel $M$, Denkert C. Evaluation of a hormone receptor-positive ovarian carcinoma subtype with a favourable prognosis by determination of progesterone receptor and oestrogen receptor 1 mRNA expression in formalin-fixed paraffin-embedded tissue. Histopathology. 2011;59(5):918-27.

7. George A, McLachlan J, Tunariu N, Della Pepa C, Migali C, Gore M, Kaye S, Banerjee $\mathrm{S}$. The role of hormonal therapy in patients with relapsed highgrade ovarian carcinoma: a retrospective series of tamoxifen and letrozole. BMC Cancer. 2017;17(1):456.

8. Kristeleit R, Davidenko I, Shirinkin V, El-Khouly F, Bondarenko I, Goodheart MJ, Gorbunova V, Penning CA, Shi JG, Liu X, et al. A randomised, open-label, phase 2 study of the IDO1 inhibitor epacadostat (INCB024360) versus tamoxifen as therapy for biochemically recurrent (CA-125 relapse)-only epithelial ovarian cancer, primary peritoneal carcinoma, or fallopian tube cancer. Gynecol Oncol. 2017;146(3):484-90.

9. Treeck O, Lattrich C, Springwald A, Ortmann O. Estrogen receptor beta exerts growth-inhibitory effects on human mammary epithelial cells. Breast Cancer Res Treat. 2010;120(3):557-65.

10. Treeck O, Juhasz-Boess I, Lattrich C, Horn F, Goerse R, Ortmann O. Effects of exon-deleted estrogen receptor beta transcript variants on growth, apoptosis and gene expression of human breast cancer cell lines. Breast Cancer Res Treat. 2008;110(3):507-20.

11. Fixemer $T$, Remberger $K$, Bonkhoff $H$. Differential expression of the estrogen receptor beta (ERbeta) in human prostate tissue, premalignant changes, and in primary, metastatic, and recurrent prostatic adenocarcinoma. Prostate. 2003:54(2):79-87.

12. Treeck O, Pfeiler G, Mitter D, Lattrich C, Piendl G, Ortmann O. Estrogen receptor $\{$ beta\} 1 exerts antitumoral effects on SK-OV-3 ovarian cancer cells. endocrinol. 2007:193(3):421-33.

13. Schuler-Toprak S, Moehle C, Skrzypczak M, Ortmann O, Treeck O. Effect of estrogen receptor beta agonists on proliferation and gene expression of ovarian cancer cells. BMC Cancer. 2017;17(1):319.

14. Schuler S, Lattrich C, Skrzypczak M, Fehm T, Ortmann O, Treeck O. Polymorphisms in the promoter region of ESR2 gene and susceptibility to ovarian cancer. Gene. 2014;546(2):283-7.

15. Chan KK, Wei N, Liu SS, Xiao-Yun L, Cheung AN, Ngan HY. Estrogen receptor subtypes in ovarian cancer: a clinical correlation. Obstet Gynecol. 2008; 111(1):144-51.

16. Rutherford T, Brown WD, Sapi E, Aschkenazi S, Munoz A, Mor G. Absence of estrogen receptor-beta expression in metastatic ovarian cancer. Obstet Gynecol. 2000;96(3):417-21.

17. Stefano ID, Stefano ID, Stefano I, Stefano I, Zannoni GF, Zannoni GF, Prisco MG, Prisco MG, Fagotti A, Fagotti A, et al. Cytoplasmic expression of estrogen receptor beta (ER $\beta$ ) predicts poor clinical outcome in advanced serous ovarian cancer. Gynecol Oncol. 2011;122(3):573-9.

18. Comamala M, Pinard M, Theriault C, Matte I, Albert A, Boivin M, Beaudin J, Piche A, Rancourt C. Downregulation of cell surface CA125/MUC16 induces epithelial-to-mesenchymal transition and restores EGFR signalling in $\mathrm{NIH}$ : OVCAR3 ovarian carcinoma cells. Br J Cancer. 2011;104(6):989-99.

19. Giannakouros P, Comamala M, Matte I, Rancourt C, Piche A. MUC16 mucin (CA125) regulates the formation of multicellular aggregates by altering beta-catenin signaling. Am J Cancer Res. 2015;5(1):219-30.

20. Akita K, Tanaka M, Tanida S, Mori Y, Toda M, Nakada H. CA125/MUC16 interacts with Src family kinases, and over-expression of its C-terminal fragment in human epithelial cancer cells reduces cell-cell adhesion. Eur J Cell Biol. 2013:92(8-9):257-63.

21. Majuri ML, Hakkarainen M, Paavonen T, Renkonen R. Carcinoembryonic antigen is expressed on endothelial cells. A putative mediator of tumor cell extravasation and metastasis. APMIS. 1994;102(6):432-8. 
22. Negishi Y, Iwabuchi H, Sakunaga H, Sakamoto M, Okabe K, Sato H, Asano G. Serum and tissue measurements of CA72-4 in ovarian cancer patients. Gynecol Oncol. 1993;48(2):148-54.

23. Tarallo R, Giurato G, Bruno G, Ravo M, Rizzo F, Salvati A, Ricciardi L, Marchese G, Cordella A, Rocco T, et al. The nuclear receptor ERbeta engages AGO2 in regulation of gene transcription, RNA splicing and RISC loading. Genome Biol. 2017;18(1):189.

24. Mirlacher M, Simon R. Recipient block TMA technique. Methods Mol Biol. 2010;664:37-44

25. Remmele W, Stegner HE. Recommendation for uniform definition of an immunoreactive score (IRS) for immunohistochemical estrogen receptor detection (ER-ICA) in breast cancer tissue. Pathologe. 1987;8(3):138-40.

26. Spaulding DC, Spaulding BO. Epidermal growth factor receptor expression and measurement in solid tumors. Semin Oncol. 2002;29(5 Suppl 14):45-54.

27. Charafe-Jauffret E, Tarpin C, Bardou VJ, Bertucci F, Ginestier C, Braud AC, Puig B, Geneix J, Hassoun J, Birnbaum D, et al. Immunophenotypic analysis of inflammatory breast cancers: identification of an 'inflammatory signature. J Pathol. 2004;202(3):265-73.

28. Lenhard M, Tereza L, Heublein S, Ditsch N, HimsI I, Mayr D, Friese K, Jeschke U. Steroid hormone receptor expression in ovarian cancer: progesterone receptor B as prognostic marker for patient survival. BMC Cancer. 2012;12:553.

29. Hogdall EV, Christensen L, Hogdall CK, Blaakaer J, Gayther S, Jacobs IJ, Christensen IJ, Kjaer SK. Prognostic value of estrogen receptor and progesterone receptor tumor expression in Danish ovarian cancer patients: from the 'MALOVA' ovarian cancer study. Oncol Rep. 2007;18(5):1051-9.

30. Lee P, Rosen DG, Zhu C, Silva EG, Liu J. Expression of progesterone receptor is a favorable prognostic marker in ovarian cancer. Gynecol Oncol. 2005; 96(3):671-7.

31. De Stefano I, Zannoni GF, Prisco MG, Fagotti A, Tortorella L, Vizzielli G, Mencaglia L, Scambia G, Gallo D. Cytoplasmic expression of estrogen receptor beta (ERbeta) predicts poor clinical outcome in advanced serous ovarian cancer. Gynecol Oncol. 2011;122(3):573-9.

32. Pietras RJ, Marquez-Garban DC. Membrane-associated estrogen receptor signaling pathways in human cancers. Clin Cancer Res. 2007;13(16):4672-6.

33. Burges A, Bruning A, Dannenmann C, Blankenstein T, Jeschke U, Shabani N, Friese K, Mylonas I. Prognostic significance of estrogen receptor alpha and beta expression in human serous carcinomas of the ovary. Arch Gynecol Obstet. 2010;281(3):511-7.

34. Foley EF, Jazaeri AA, Shupnik MA, Jazaeri O, Rice LW. Selective loss of estrogen receptor beta in malignant human colon. Cancer Res. 2000;60(2): 245-8.

35. Luo H, Li S, Zhao M, Sheng B, Zhu H, Zhu X. Prognostic value of progesterone receptor expression in ovarian cancer: a meta-analysis. Oncotarget. 2017;8(22):36845-56.

36. Lindgren P, Backstrom T, Mahlck CG, Ridderheim M, Cajander S. Steroid receptors and hormones in relation to cell proliferation and apoptosis in poorly differentiated epithelial ovarian tumors. Int J Oncol. 2001;19(1):31-8.

37. van Kruchten $M$, van der Marel $P$, de Munck L, Hollema H, Arts H, TimmerBosscha H, de Vries E, Hospers G, Reyners A. Hormone receptors as a marker of poor survival in epithelial ovarian cancer. Gynecol Oncol. 2015;138(3):634-9.

38. Sylvia MT, Kumar S, Dasari P. The expression of immunohistochemical markers estrogen receptor, progesterone receptor, Her-2-neu, p53 and Ki-67 in epithelial ovarian tumors and its correlation with clinicopathologic variables. Indian J Pathol Microbiol. 2012;55(1):33-7.

39. Park SH, Cheung LW, Wong AS, Leung PC. Estrogen regulates snail and slug in the down-regulation of E-cadherin and induces metastatic potential of ovarian cancer cells through estrogen receptor alpha. Mol Endocrinol. 2008; 22(9):2085-98

40. Akahira J, Inoue T, Suzuki T, Ito K, Konno R, Sato S, Moriya T, Okamura K Yajima A, Sasano H. Progesterone receptor isoforms A and B in human epithelial ovarian carcinoma: immunohistochemical and RT-PCR studies. Br J Cancer. 2000;83(11):1488-94.

Ready to submit your research? Choose BMC and benefit from:

- fast, convenient online submission

- thorough peer review by experienced researchers in your field

- rapid publication on acceptance

- support for research data, including large and complex data types

- gold Open Access which fosters wider collaboration and increased citations

- maximum visibility for your research: over $100 \mathrm{M}$ website views per year

At BMC, research is always in progress.

Learn more biomedcentral.com/submissions 